\title{
ŪMUS PANKREATITAS. ETIOLOGIJA, DIAGNOSTIKA IR PRADINIS GYDYMAS
}

\author{
Juozas Rimkus \\ Vilniaus universiteto Medicinos fakultetas
}

\begin{abstract}
Raktažodžiai: ūmus pankreatitas, ūmaus pankreatito etiologija, ūmaus pankreatito gydymas.
\end{abstract}

\begin{abstract}
Santrauka
Ūmus pankreatitas yra kasos uždegimas. Tai nenuspèjama ir potencialiai mirtina liga. Nors daugumai pacientų pasireiškia lengvas ūmus pankreatitas, iki 20-30 proc. atvejų jis gali būti vidutinio sunkumo ar sunkus, nuo kurio mirštamumas siekia 15-17 procentų. Tyrimo tikslas - susipažinti su ūmaus pankreatito etiologija, diagnostika ir gydymu. Literatūros paieška atlikta PubMed, ClinicalKey, ScienceDirect, Google Scholar duomenu bazèse. Naudoti raktažodžiai: acute pancreatitis, treatment, diagnosis, etiology. Iš viso atrinkta ir išanalizuota 15 publikacijų, paskelbtų 2015-2021 metų laikotarpiu. Tyrimo rezultatai. Dažniausia ūmaus pankreatito priežastis yra tulžies pūslès akmenligè ar ilgalaikis gausus alkoholio vartojimas. Etiologija gali skirtis priklausomai nuo šalies ar regiono. Ūmiam pankreatitui diagnozuoti reikalinga tipiška klinika, padidèjęs kasos fermentu (amilazès ir (ar) lipazès) kiekis kraujo serume ir ūmiam pankreatitui būdingi radiologinių tyrimų radiniai. Pradiniam gydymui svarbiausia tinkama skysčių terapija, kurios adekvatumas vertinamas pagal gyvybiniu parametrų reikšmes, hematokritą ir šlapimo kiekį. Kadangi skausmas yra labai būdingas ūmaus pankreatito požymis, reikalingas tinkamas nuskausminimas, vadovaujantis Pasaulio sveikatos organizacijos skausmo malšinimo pakopomis. Jei nepatenkinamas energijos poreikis, enterini maitinimą pradèti praejjus 72 val. nuo simptomu pradžios. Tolesnis ūmaus pankreatito gydymas priklauso nuo ligos etiologijos ir komplikacijų.
\end{abstract}

\section{Ivadas}

Ūmus pankreatitas - tai kasos uždegimas. Jam būdingas pilvo skausmas ir padidejjęs kasos fermentų (amilazès ir (ar) lipazès) kiekis kraujyje. Ūmus pankreatitas yra dažniausia gastroenterologinè patologija, dèl kurios reikalinga hospi- talizacija (dažnis 4,9-45 atvejai 100000 gyventojų) [1-3]. Daugumai pacientų pasireiškia lengvas ūminis pankreatitas, kurio simptomai praeina maždaug per vieną savaitę, tačiau apie 20-30 proc. atvejų pasitaiko vidutinio sunkumo ar sunkus ūminis pankreatitas, nuo kurio mirštamumas siekia 15-17 proc. (specializuotuose centruose 6-9\%) $[1,2,4]$. Dažniausios ūminio pankreatito priežastys yra tulžies pūslès akmenys ir alkoholis [5]. Rūkymas galimai padidina pankreatito, nesusijusio su tulžies pūslès akmenlige, riziką ir sustiprina alkoholio sukeltą kasos pažeidimą [1]. Nèra jokio specifinio ūminio pankreatito gydymo. Stebimos gyvybinès funkcijos, skysčių balansas, užtikrinama pakankama mityba ir adekvatus nuskausminimas [2]. 3-13 proc. ūmaus pankreatito atvejų pereina ị lètini [6].

Tyrimo tikslas - susipažinti su ūmaus pankreatito etiologija, diagnostika ir gydymu.

\section{Tyrimo medžiaga ir metodai}

Literatūros paieška atlikta PubMed, ClinicalKey, ScienceDirect, Google Scholar duomenų bazèse. Naudoti raktažodžiai: acute pancreatitis, treatment, diagnosis, etiology. Iš viso atrinkta ir išanalizuota 15 publikacijų, paskelbtų 20152021 metų laikotarpiu.

\section{Tyrimo rezultatai}

Etiologija. Dabartinès gairès rekomenduoja kuo anksčiau išsiaiškinti ūmaus pankreatito priežastị [2]. Dažniausia ūmaus pankreatito priežastis (40-70\% atvejų) yra tulžies pūslès akmenys. Didesnè rizika vyrams, esant mažiems akmenims $(<5 \mathrm{~mm})$, nes jie daug dažniau nei didesni sukelia didžiojo dvylikapirštes žarnos spenelio obstrukciją [1]. Ilgalaikis alkoholio vartojimas sukelia apie 17-35 proc. ūmaus pankreatito atvejų. Paprastai ūmus pankreatitas išsivysto per $\geq 5$ metus, kai suvartojama 4-5 standartiniai alkoholio vienetai per dieną, kartais - retai suvartojant dideli alkoholio kiekį. Rūkalių, suvartojančių $>400 \mathrm{~g}$ alkoholio per mènesį, 4 kartus didesnè (iki 20\%) ūmaus pankreatito tikimybé, nei tik gausiai vartojančių alkoholị $(\approx 5 \%)[1,7]$. Hipertrigliceride- 
mija taip pat gali sukelti ūmų pankreatitą. Jei trigliceridų kiekis kraujyje yra $>10 \mathrm{mmol} / \mathrm{l}$, ūmaus pankreatito tikimybè yra iki 5 procentų. Jei trigliceridų kiekis $>20 \mathrm{mmol} / \mathrm{l}$, tikimybè didejja 10-20 procentų [8]. Ūmus pankreatitas gali išsivystyti po endoskopinès retrogradinès cholangiopankreatografijos (ERCP). Ūmaus pankreatito rizika po ERCP yra 3,5 procento. Riziką didinantys veiksniai: moteriška lytis, buvęs pankreatitas, buvęs pankreatitas po ERCP, Oddi sfinkterio disfunkcija $[1,9]$. Retai $(<5 \%$ atvejų) ūmų pankreatitą gali sukelti vaistai. Tai angiotenziną konvertuojančio fermento inhibitoriai, statinai, kontraceptikai ar pakaitinè hormonų terapija, diuretikai, valproatai ir kiti [6]. Retesnès ūmaus pankreatito priežastys: hiperkalcemija, autoimuninès ligos (sisteminè raudonoji vilkligè), trauma, genetinès priežastys $(\alpha-1$ antitripsino stoka) $[2,10]$. Pankreatito etiologija skiriasi priklausomai nuo regiono. Tulžies pūslès akmenligès sukeltas pankreatitas dominuoja Viduržemio jūros regione, alkoholio - Rytų Europoje, o Šiaurès ir Vakarų Europoje tulžies pūslès akmenligès ir alkoholio sukelto ūmaus pankreatito atvejų skaičius yra maždaug vienodas [11].

Diagnostika. Pacientas, sergantis ūmiu pankreatitu, dažniausiai jaučia vidutinio stiprumo ar stiprų viršutinio pilvo aukšto skausmą, pykinimą, neturi apetito. Skausmas gali skirtis, priklausomai nuo ligos priežasties. Esant tulžies pūslès akmenų sukeltam pankreatitui, skausmas dažniau prasidès staigiai, bus aštrus, plintantis ị nugarą. Palaipsniui stiprèjantis skausmas, bukesnio pobūdžio, apimantis visą pilvą ar sunkiai nusakomos lokalizacijos labiau būdingas toksinès (pvz. alkoholio sukeltam) ar metabolinès kilmès pankreatitui [10]. Esant sunkiam ūmiam pankreatitui, gali būti dusulys dèl antrinio diafragmos uždegimo, skysčio pleuros ertmèje ar ūmaus respiracinio distreso sindromo [12]. Palpuojant pilvą, skausmingas epigastriumas, galimas raumenų tempimas. Dèl antrinio žarnų nepraeinamumo pilvas gali būti išpūstas, susilpnejusi peristaltika $[10,12]$. Kasos fermentų padidejjimas kraujo serume, bent 3 kartus aukščiau viršutinès normos ribos, laikomas ūmaus pankreatito diagnostikos aukso standartu. Amilazès kiekis pradeda didèti 6-24 h, aukščiausią tašką pasiekia $48 \mathrm{~h}$, o iki normos nukrenta 3-7 dieną. Lipazès kiekis padidėja 4-8 h, aukščiausią tašką pasiekia 24 h, o iki normos nukrenta 8-14 dieną. Lipazè laikoma labiau patikimu žymekliu, nei amilazė [4]. Laboratoriniai tyrimai gali rodyti tulžies stazę, hiperkalcemiją ar ryškią hiperlipidemiją, o tai gali padèti nustatyti pankreatito priežastį [10]. C reaktyvaus baltymo kiekis $>150 \mathrm{mg} / \mathrm{l}$, nustatytas per pirmas $72 \mathrm{~h}$, rodo sunkų ūmų pankreatitą. Hematokritas $>44$ proc. yra nepriklausomas kasos nekrozès rizikos veiksnys, o prokalcitoninas yra jautriausias laboratorinis tyrimas, leidžiantis įtarti kasos nekrozès infekciją [4]. Ultragarsinio tyrimo nauda yra ribota, pagrindinè šio tyrimo funkcija - pankreatito etiologijos nu- statymas. Ultragarsu galima nustatyti akmenis tulžies pūsleje ar bendrajame tulžies latake [13]. Vidutinio sunkumo ir sunkaus ūmaus pankreatito atveju reikia atlikti kompiuterinę tomografiją su intraveniniu kontrastavimu arba magnetinio rezonanso tyrimą su intraveniniu kontrastavimu. Optimalus laikas atlikti tyrimą yra 72-96 h nuo simptomų pradžios [4]. Ümaus pankreatito diagnozei patvirtinti reikalingi bent du iš šių trijų požymių: tipiškas pilvo skausmas, amilazès ir(ar) lipazès kiekis kraujo serume bent 3 kartus viršija viršutinę normos ribą, ūmiam pankreatitui tipiški radiniai atliktuose vaizdo tyrimuose [2].

Gydymas. Pradinio ūmaus pankreatito gydymo esmè - adekvati skysčių terapija. Taip siekiama išvengti hipovolemijos ir organų hipoperfuzijos. Rekomenduojama 5-10 $\mathrm{ml} / \mathrm{kg} / \mathrm{val}$. Ringerio laktato infuzija. Terapijos adekvatumui vertinti naudojamos siektinos gyvybinių parametrų reikšmès: širdies susitraukimų dažnis $<120 \mathrm{k} / \mathrm{min}$, , vidutinis arterinis kraujospūdis $65-85 \mathrm{mmHg}$, šlapimo kiekis $>0,51$ $\mathrm{ml} / \mathrm{kg} / \mathrm{val}$., hematokritas $35-44$ procentai $[1,5,10]$. Skausmas yra vienas pagrindinių ūmaus pankreatito simptomų, todèl pakankamas nuskausminimas yra būtinas. Vadovaujamasi Pasaulio sveikatos organizacijos skausmo malšinimo pakopomis. Jei reikia, opioidiniai analgetikai yra saugūs ir efektyvūs, gydant ūminio pankreatito sukeltą skausmą. Esant ūmiam inkstų pažeidimui, rekomenduojama vengti nesteroidinių vaistų nuo uždegimo $[1,2,4]$. Jei pacientas negali suvartoti pakankamai kalorijų, enterini maitinimą rekomenduojama pradèti praejjus 72 val. nuo simptomų atsiradimo. Parenterinis maitinimas nerekomenduojamas [2]. Antriné kasos nekrozés infekcija, manoma, atsiranda dèl bakterijų translokacijos iš žarnyno, tačiau profilaktinè antibiotikoterapija susijusi su rezistentiškų bakterijų atsiradimu, todèl nerekomenduojama. Esant kasos nekrozès infekcijos požymių, galima rinktis iš šių antibiotikų: karbapenemai, piperacilinas su tazobaktamu, trečios kartos cefalosporinai, fluorochinolonas su metronidazoliu [14]. Tolesnis ūmaus pankreatito gydymas priklauso nuo ji sukèlusios priežasties ir komplikacijų. Tulžies pūslès akmenligès atveju rekomenduojama cholecistektomija, o jei kartu yra ir cholangitas, rekomenduojama atlikti ERCP per 24 val. nuo simptomų atsiradimo [10]. Esant infekuotai kasos nekrozei, dažnai prireikia ir invazyvaus gydymo (perkutaninio, endoskopinio ar operacinio) [4].

\section{Išvados}

1. Dažniausios ūmaus pankreatito priežastys yra tulžies pūslès akmenys ir ilgalaikis gausus alkoholio vartojimas.

2. Ūmaus pankreatito diagnozei patvirtinti reikalingi du iš šių trijų kriterijų: tipiškas pilvo skausmas, amilazės ir(ar) lipazès kiekis kraujo serume bent 3 kartus viršija viršutinę 
normos ribą, ūmiam pankreatitui tipiški radiniai atliktuose vaizdo tyrimuose.

3. Ūmaus pankreatito gydymas pradedamas adekvačia skysčių terapija ir skausmo malšinimu.

\section{Literatūra}

1. Vege SS. Etiology of acute pancreatitis. UpToDate. 2021. https://www.uptodate.com/contents/etiology-of-acutepancreatitis?Search $=$ acute $\% 20$ pancreatitis\&source $=$ search_re sult\&selectedtitle $=3 \sim 150 \&$ usage_type $=$ default $\&$ display_ rank $=3$

2. Boxhoorn L, Voermans RP, Bouwense SA, Bruno MJ, Verdonk RC, Boermeester MA, et al. Acute pancreatitis. The Lancet 2020;396(10252):726-34.

https://doi.org/10.1016/S0140-6736(20)31310-6

3. Ismail OZ, Bhayana V. Lipase or amylase for the diagnosis of acute pancreatitis? Clin Biochem 2017;50(18):1275-80.

https://doi.org/10.1016/j.clinbiochem.2017.07.003

4. Leppäniemi A, Tolonen M, Tarasconi A, Segovia-Lohse H, Gamberini E, Kirkpatrick AW, et al. 2019 WSES guidelines for the management of severe acute pancreatitis. World J Emerg Surg 2019;14(1):27.

https://doi.org/10.1186/s13017-019-0247-0

5. Crockett SD, Wani S, Gardner TB, Falck-Ytter Y, Barkun AN, Crockett S, et al. American Gastroenterological Association Institute Guideline on Initial Management of Acute Pancreatitis. Gastroenterology 2018;154(4):1096-101. https://doi.org/10.1053/j.gastro.2018.01.032

6. Jones MR, Hall OM, Kaye AM, Kaye AD. Drug-induced acute pancreatitis: a review. Ochsner J 2015;15(1):45-51.

https://www.ncbi.nlm.nih.gov/pmc/articles/PMC4365846/

7. Klochkov A, Kudaravalli P, Sun Y. Alcoholic pancreatitis. Stat Pearls Publishing 2021. http://www.ncbi.nlm.nih.gov/books/ NBK537191/

8. Olesen SS, Harakow A, Krogh K, Drewes AM, Handberg A, Christensen PA. Hypertriglyceridemia is often under recognized as an aetiologic risk factor for acute pancreatitis: a population-based cohort study. Pancreatology 2021;21(2):334-41. https://doi.org/10.1016/j.pan.2021.02.005

9. Ding X, Zhang F, Wang Y. Risk factors for post-ERCP pancreatitis: a systematic review and meta-analysis. Surgeon 2015;13(4):218-29.

https://doi.org/10.1016/j.surge.2014.11.005

10. Gapp J, Chandra S. Acute pancreatitis. StatPearls Publishing 2021. http://www.ncbi.nlm.nih.gov/books/NBK482468/

11. Roberts SE, Morrison-Rees S, John A, Williams JG, Brown TH, Samuel DG. The incidence and aetiology of acute pancreatitis across Europe. Pancreatology 2017; 17(2):155-65.

https://doi.org/10.1016/j.pan.2017.01.005

12. Vege SS. Clinical manifestations and diagnosis of acute pancreatitis. UpToDate 2021. https://www.uptodate.com/ contents/clinical-manifestations-and-diagnosis-of-acutepancreatitis?Search $=$ acute $\% 20$ pancreatitis \&source $=$ search_re sult\&selectedtitle $=2 \sim 150 \&$ usage_type $=$ default\&display_ rank $=2$

13. Baleato-González S, García-Figueiras R, Junquera-Olay S, Canedo-Antelo M, Casas-Martínez J. Imaging acute pancreatitis. Radiol Engl Ed 2021;63(2):145-58. https://doi.org/10.1016/j.rxeng.2020.10.005

14. Wolbrink DRJ, Kolwijck E, Ten Oever J, Horvath KD, Bouwense SAW, Schouten JA. Management of infected pancreatic necrosis in the intensive care unit: a narrative review. Clin Microbiol Infect 2020;26(1):18-25.

https://doi.org/10.1016/j.cmi.2019.06.017

\section{ACUTE PANCREATITIS. ETIOLOGY, DIAGNOSIS AND INITIAL MANAGEMENT J. Rimkus}

Keywords: acute pancreatitis, treatment, diagnosis, etiology. Summary

Acute pancreatitis is an inflammatory condition of the pancreas. The course of the disease is unpredictable and potentially lethal. Although the majority of patients with acute pancreatitis have a mild disease, up to $20-30 \%$ develops a severe form with associated mortality of $15-17 \%$. It is most often caused by bile stones or chronic substantial ( $4-5$ drinks daily) alcohol consumption, but the rate of occurrence of each etiology may differ between different countries or regions. The diagnosis requires at least two of three criteria: typical abdominal pain, elevated serum amylase and/or lipase values (at least 3 times the upper limit of normal), characteristic findings of abdominal imaging. Fluid therapy to prevent hypovolemia and organ hypoperfusion is the cornerstone of initial treatment. Adequate fluid replacement can be assessed by an improvement of vital signs, urine output or reduced hematocrit. Pain is the most predominating symptom and its relief is necessary (follow World Health Organization's pain management ladder). Enteral feeding can be started after $72 \mathrm{~h}$ if the patient has insufficient caloric intake. Further management depends on the etiology and complications of acute pancreatitis.

Correspondence to: juozas.rimkus96@gmail.com

Gauta 2021-04-29 